\title{
Antibacterial Activity of Skin and Intestinal Mucus of Five Different Freshwater Fish Species Viz., Channa striatus, $C$. micropeltes, $C$. marulius, $C$. Punctatus and C. gachua
}

\section{Dhanaraj M., Haniffa M.A*., Arun Singh S.V., Muthu Ramakrishnan C., Manikandaraja D. and James Milton M.}

Centre for Aquaculture Research and Extension, St. Xavier's College (Autonomous), Palayamkottai, 627002 India.

*haniffacare@gmail.com (correspondingauthor)

Received on $24^{\text {th }}$ September 2009, accepted in revised form $17^{\text {th }}$ November 2009.

\begin{abstract}
In the present investigation, efforts have were made to investigate out the antibacterial activity of skin mucus and intestinal mucus of five different Channa sp viz; Channa striatus, C. micropeltes, C. marulius, C. punctatus and $C$. gachua. The mucus collected were tested against five pathogenic bacteria namely Aeromonas hydrophila, Pseudomonas aeruginosa, Escherichia coli, Vibrio fischeri and V. anguillarum using Muller Hinton agar plates by using disc diffusion method. All the five Channa sp showed a better antibacterial activity and among the five species $C$. striatus showed a broad spectrum of antibacterial activity of skin mucus against $A$. hydrophila $(19.5 \pm 2 \mathrm{~mm})$. $P$. aeruginosa $(28 \pm 2.9 \mathrm{~mm})$ and $V$. anguillarum $(24.5 \pm 2.4 \mathrm{~mm})$ and intestinal mucus against $A$. hydrophila $(16 \pm 1.4 \mathrm{~mm})$, P. aeruginosa $(29 \pm 3.2 \mathrm{~mm})$, V. anguillarum $(18.3 \pm 1.5 \mathrm{~mm})$ and $V$. fischeri $(21.5 \pm 1.8)$. Among the five pathogens tested the maximum antibacterial activity was observed for the skin mucus against $V$. fischeri and the intestinal mucus against $P$. aeruginosa..
\end{abstract}

(Keywords: Channa sp, Aeromonas hydrophila, Pseudomonas aeruginosa, Escherichia coli, Vibrio fischeri \& V.anguillarum.)

\section{INTRODUCTION}

Animals in the aquatic environment consist of bacterial flora which is a reflection of the microflora present in the environment [1]. The most critical aspect of the environment for fish welfare is defined by their intimate contact with the medium through gills and skin [2]. The skin acts as a mechanical barrier by preventing the entry of microbes into the body [3]. Potentially valuable proteins and enzymes are present in the fish by products [4] and these compounds and the antagonistic bacteria help prevention of invading bacterial diseases. Virtually all fishes are covered with integumental mucus that is involved in many aspects of their biology, ranging from disease resistance to rearing of youngones to shelter and locomotion. Quite extensive work has been done on the skin of various teleosts during the past decades but only few studies have been carried out with regard to fish skin. It was reported that epithelial tissues produce antimicrobial molecules which serve as the first line of a host's defense against microbial invasion in a variety of vertebrates including humans [5]. Since the microorganisms have developed resistance to many antibiotics there is a need to develop an alternative antimicrobial drug. Antibacterial activity of mucus has been demonstrated in various fish species [6] but it varies from species to species [7].

Murrels commonly called snakeheads belonging to the genus Channa are highly priced among the freshwater fishes for their quality, taste, flavour and nutritive, recuperative and medicinal properties [8,9]. The present study was undertaken to determine the antibacterial activity of skin mucus and intestinal mucus of five different Channa sp (C. striatus, $C$. micropeltes, $C$. marulius, $C$. punctatus and $C$. gachua) against five pathogens viz; Aeromonas hydrophila, Pseudomonas aeruginosa, Escherichia coli, Vibrio fischeri and V. anguillarum.

\section{MATERIAL AND METHODS}

\section{Collection of Fish}

Healthy fish from each Channa $s p$ approximately of 500 - 700g (C. micropeltes \& C. marulius) were purchased from Kerala, 500 - 600g (C. striatus), 200 - 250g (C. punctatus) and 30 - 40g (C. gachua) were collected from fish market Tirunelveli, Tamilnadu $\left(8.41^{\circ} \mathrm{N}, 77.44^{\circ} \mathrm{E}\right)$, India. They were transported to Centre for Aquaculture Research and Extension (CARE) Aquafarm and reared separately in cement tanks ( $3 \mathrm{~m} \times 3 \mathrm{~m} \times 1 \mathrm{~m})$ for a period of ten days. 


\section{Collection of mucus}

The entire five different Channa $s p$ were kept in sterilized water in fibre tanks (1000 1 capacity) for an hour prior to mucus collection. The disease free fish samples were taken and the skin mucus $(0.5 \mathrm{ml})$ was collected from the whole body. The intestinal mucus $(0.2 \mathrm{ml})$ was collected by sacrificing the fish samples and then the mucus was collected by separating the intestine from the internal organs [10]. Equal amount of sterile physiological saline $(0.85 \% \mathrm{NaCl})$ was added to the mucus and centrifuged at $5000 \mathrm{rpm}$ for $15 \mathrm{~min}$. The supernatant was collected and stored at $4^{0} \mathrm{C}$ for further use.

\section{Bacterial strains}

The in vitro antimicrobial evaluation of mucus of five different Channa $s p$ was carried out against five bacteria viz; A. hydrophila, P. aeruginosa, E. coli, V. fischeri and $V$. anguillarum. All the five bacterial strains were freshly cultured (18 - $24 \mathrm{hr})$ from the mother culture preserved in CARE microbiology laboratory.

\section{Antimicrobial activity}

Antimicrobial activity was determined by using disc diffusion method. $0.1 \mathrm{ml}$ of each culture was swabbed separately on priorly prepared sterile Muller Hinton agar plates. Sterilized No.1 Whatmann filter paper discs were loaded with $100 \mu$ l of mucus supernatant separately for each fish sample and dried. The dried discs were impregnated on the pathogen inoculated Muller Hinton agar plates and triplicates were maintained. Then the plates were incubated at $37^{0} \mathrm{C}$ for $24 \mathrm{hr}$. Clear inhibition zones around the discs indicated the antibacterial activity [11].

\section{RESULTS AND DISCUSSIONS}

The skin and intestinal mucus of Channa sp showed a strong inhibition against the selected pathogens. The skin mucus of $C$. punctatus and C. marulius exhibited a maximum zone of inhibition against $V$. fischeri $(29$ $\pm 3 \mathrm{~mm})$ and $E$. coli $(24 \pm 2.5 \mathrm{~mm})$ respectively followed by $C$. striatus against A. hydrophila (19.5 \pm $2 \mathrm{~mm}), \quad P$. aeruginosa $(28 \pm 2.9 \mathrm{~mm})$ and $V$. anguillarum $(24.5 \pm 2.4 \mathrm{~mm})$. Whereas the minimum zone of inhibition was observed in the skin mucus of C. gachua against $A$. hydrophila $(10 \pm 1.5 \mathrm{~mm})$ and $E$. coli $(18 \pm 1.5 \mathrm{~mm})$. In the case of intestinal mucus $C$. striatus elucidated a maximum inhibition against $A$. hydrophila $(16 \pm 1.4 \mathrm{~mm})$, $P$. aeruginosa $(29 \pm$ $3.2 \mathrm{~mm}), V$. anguillarum $(18.3 \pm 1.5 \mathrm{~mm})$ and $V$. fischeri $(21.5 \pm 1.8)$ followed by $C$. marulius against E. coli $(20.3 \pm 2 \mathrm{~mm})$. In contrast the least zone of inhibition was shown by $C$. gachua against $A$. hydrophila $(7.5 \pm 1 \mathrm{~mm})$. The antibacterial activity of skin and intestinal mucus of the entire five Channa $s p$ was found to be less against $A$. hydrophila when compared to the other pathogens. The maximum antibacterial activity was observed in the skin mucus of all the five Channa $s p$ against $V$. fischeri and for the intestinal mucus against $P$. aeruginosa.

The mucus membrane present in fish skin and lining of the alimentary canal, respiratory and urogenital tracts prevents the entry of foreign microbes into the body. In addition the natural flora present on the surface of epithelial cells of mucosal surfaces of the host competes with the pathogenic bacteria [12] and prevents colonization of bacteria, fungi and parasites [6]. Mucus layer is composed of biochemical secretions from epidermal and epithelial cells [13] and plays a multirole viz; osmoregulation, reduction of friction and disease resistance [14]. The extracts of skin mucus of murrels have antiseptic [15] and antiinflammatory properties [16]. The presence of high amount of arachidonic acid and essential aminoacids in C. striatus helps in wound healing and promotes tissue growth [17]. Mat Jais et al., [18] have reported that ethanol added crude extract of $C$. striatus exhibited antifungal activity. In our investigation $C$. striatus showed a broad spectrum of antibacterial activity against $A$. hydrophila, $P$. aeruginosa, $V$. anguillarum and $V$. fischeri. In the present study the skin mucus of $C$. punctatus exhibited a minimum zone against $E$. coli $(11 \mathrm{~mm})$ and $P$. aeruginosa $(20$ $\mathrm{mm})$. Similarly $C$. gachua exhibited a least zone of inhibition against $E$. coli $(18 \pm 1.5 \mathrm{~mm})$. A better zone of inhibition was observed against $E$. coli $(22 \pm$ $2 \mathrm{~mm})$ and $P$. aeruginosa $(26 \pm 2.4 \mathrm{~mm})$ by skin mucus of $C$. punctatus. Similar findings have been reported by Kuppulakshmi et al., [11] for the antibacterial activity of skin mucus of $C$. punctatus against ten bacterial strains.

Birkemo et.al., [19] have reported that hipposin a histone derived AMP (antimicropeptide) present in the skin mucus of Atlantic halibut possesses strong antimicrobial activity against several Gram positive and Gram negative bacteria. Previous authors reported maximum inhibition by $C$. punctatus and Cirrhinus mrigala against $V$. cholarae [11]. Similarly in our study the skin and intestinal mucus of all the five different Channa $s p$ showed a significant inhibition against Vibrio $s p$ (V. fischeri and $V$. anguillarum). Fish tissues and body contain naturally occurring proteins and glycoproteins of non immunoglobulin nature (transferrins, metallothionein) that react with environmental antigens and confer an undefined natural immunity to fish. Hence several endogenous peptides with antimicrobial activity have been purified from fish 
especially from the skin and intestinal mucus [20]. The metal ion chelating mechanism exhibited by these compounds deprives the microbes of essential inorganic ion sources and thus inhibiting the microorganisms. Fish also contain lectins which has antifungal and antibacterial activities [21].

In the present study the skin and intestinal mucus of the entire five Channa $s p$ showed better antibacterial activity and in particular $C$. striatus showed a broad spectrum of antibacterial activity inhibiting the growth of all the five pathogens tested. These results suggest that fish mucus has antibacterial proteins that make the membrane to act as a barrier. Moreover the mucus of fish possesses antimicrobial agents which could be formulated in new drugs for the therapy of infectious diseases caused by pathogenic organisms. This study has to be subjected to further evaluation to analyze the chemical composition of mucus to reveal its mode of action against microorganisms.

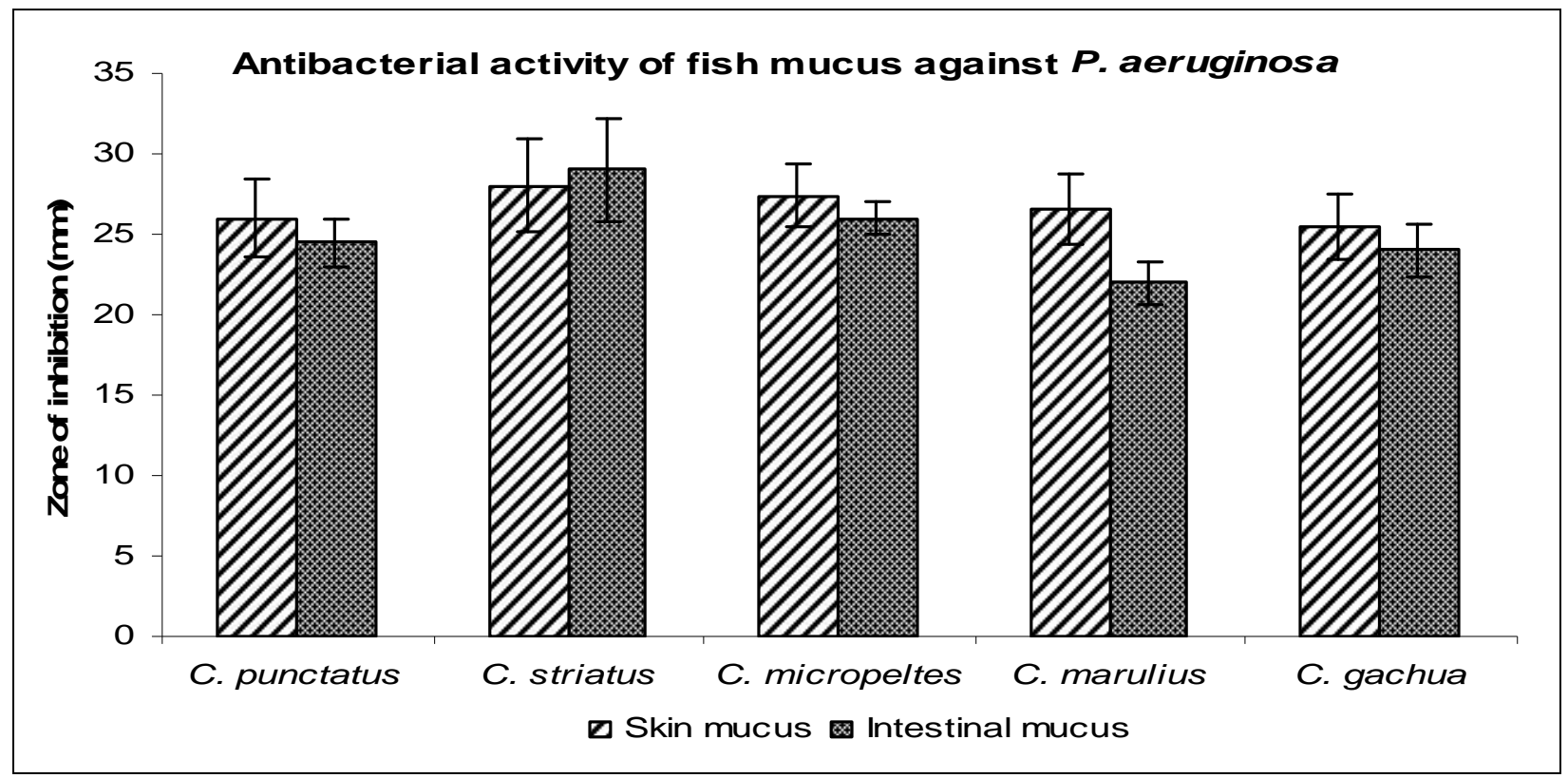

Figure 1. Antibacterial activity of skin mucus and intestinal mucus of five different Channa species against P.Aeruginosa.

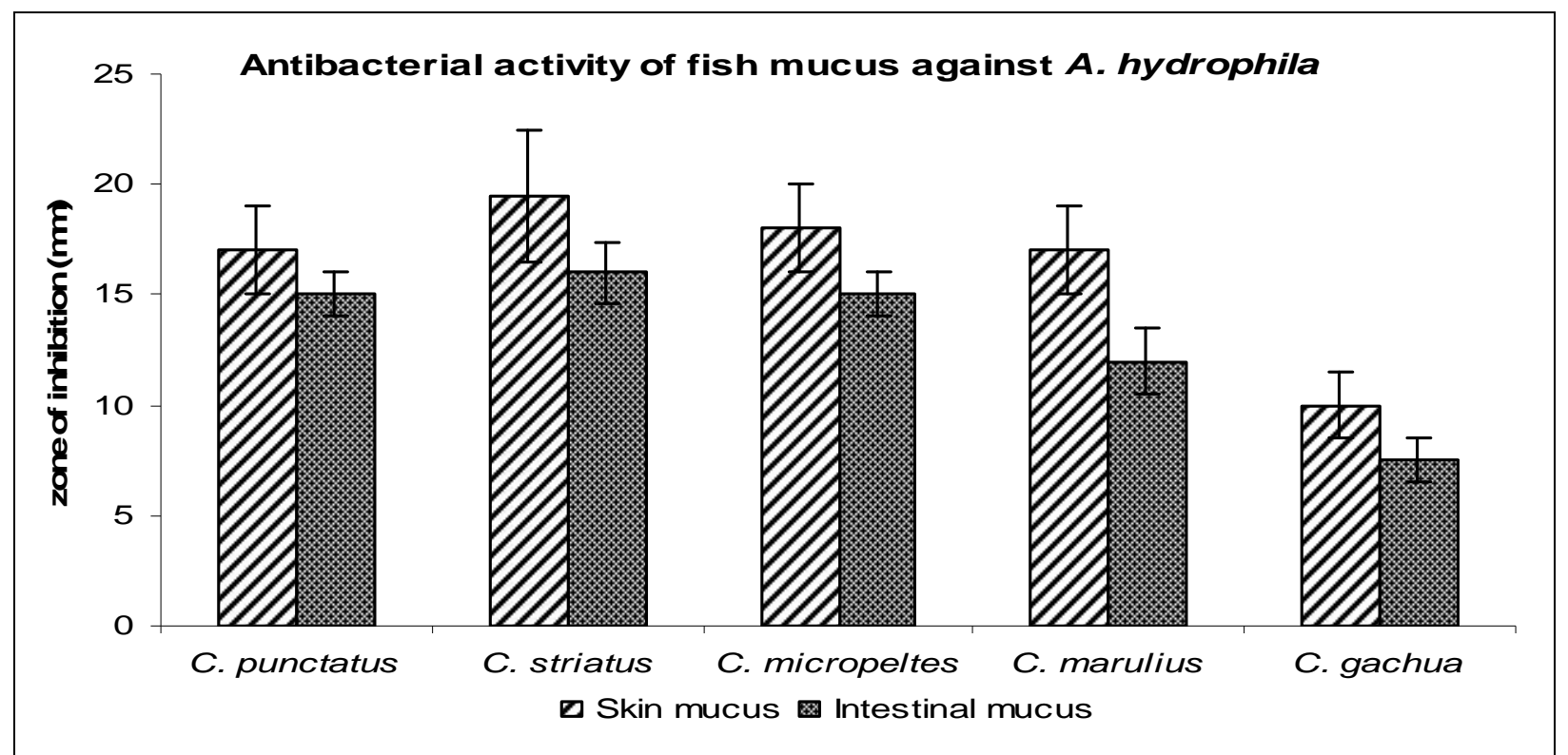

Figure 2. Antibacterial activity of skin mucus and intestinal mucus of five different Channa species against $A$. Hydrophila. 


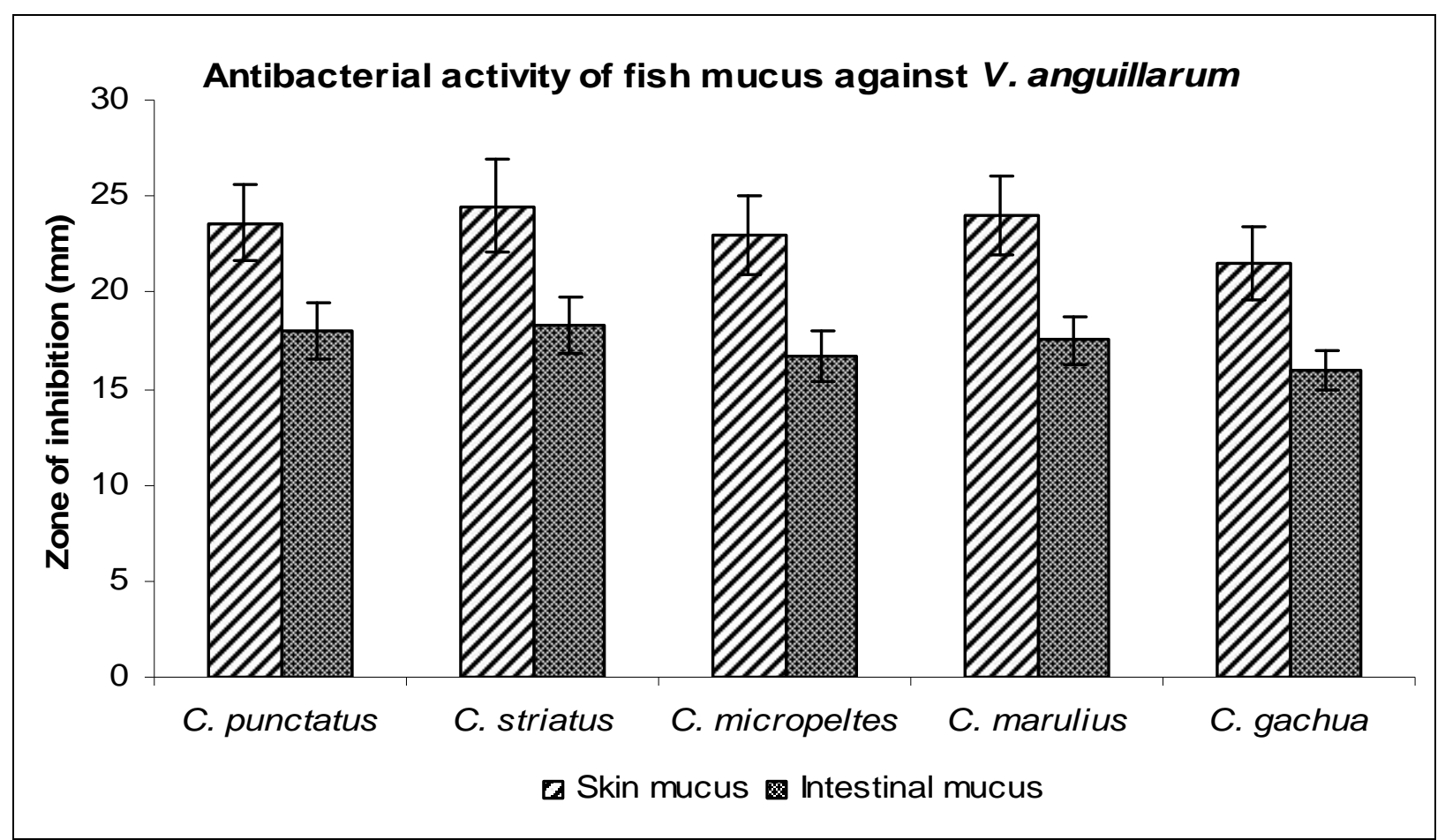

Figure 3. Antibacterial activity of skin mucus and intestinal mucus of five different Channa species against $V$. anguillarum.

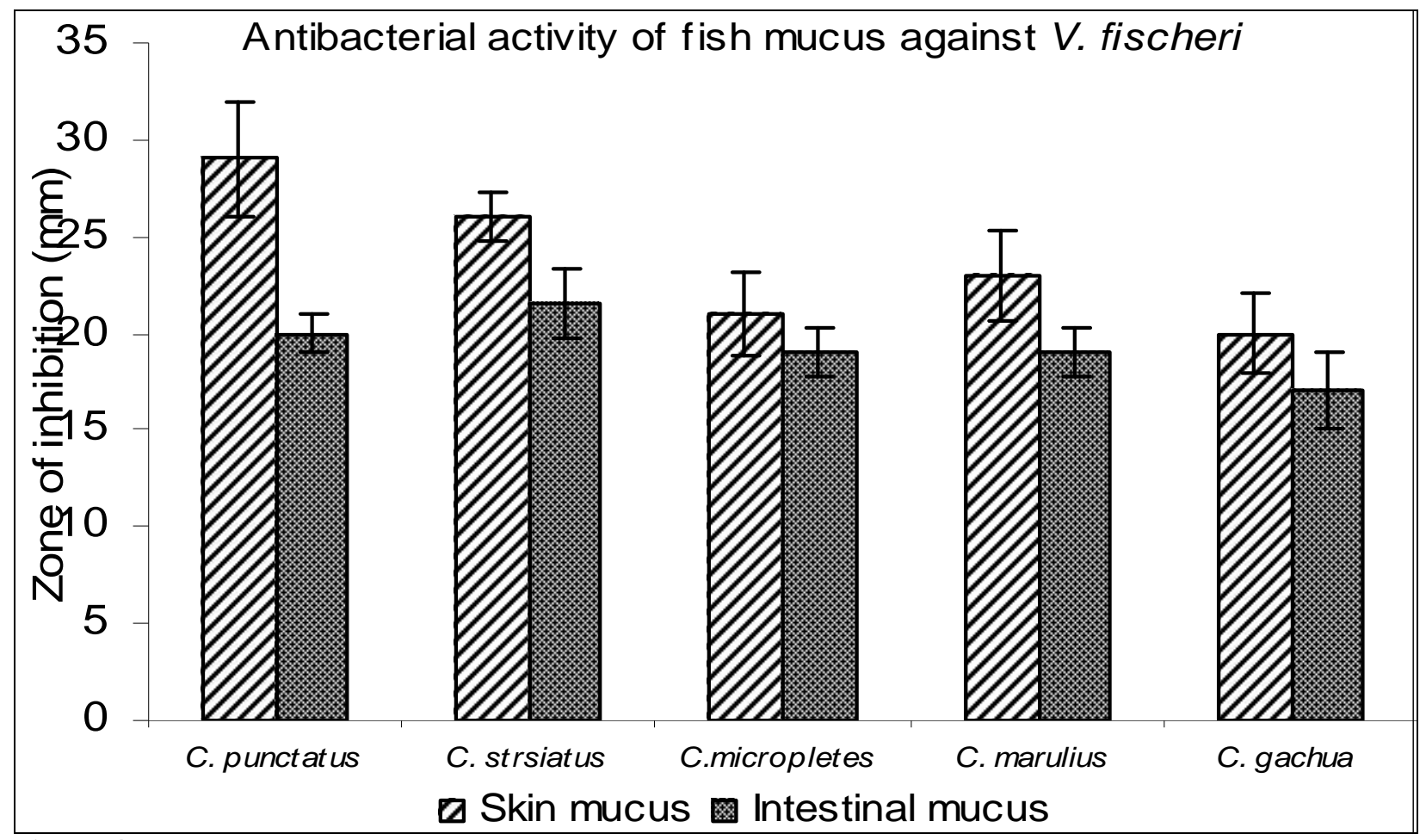

Figure 4. Antibacterial activity of skin mucus and intestinal mucus of five different Channa species against $V$. fischeri 


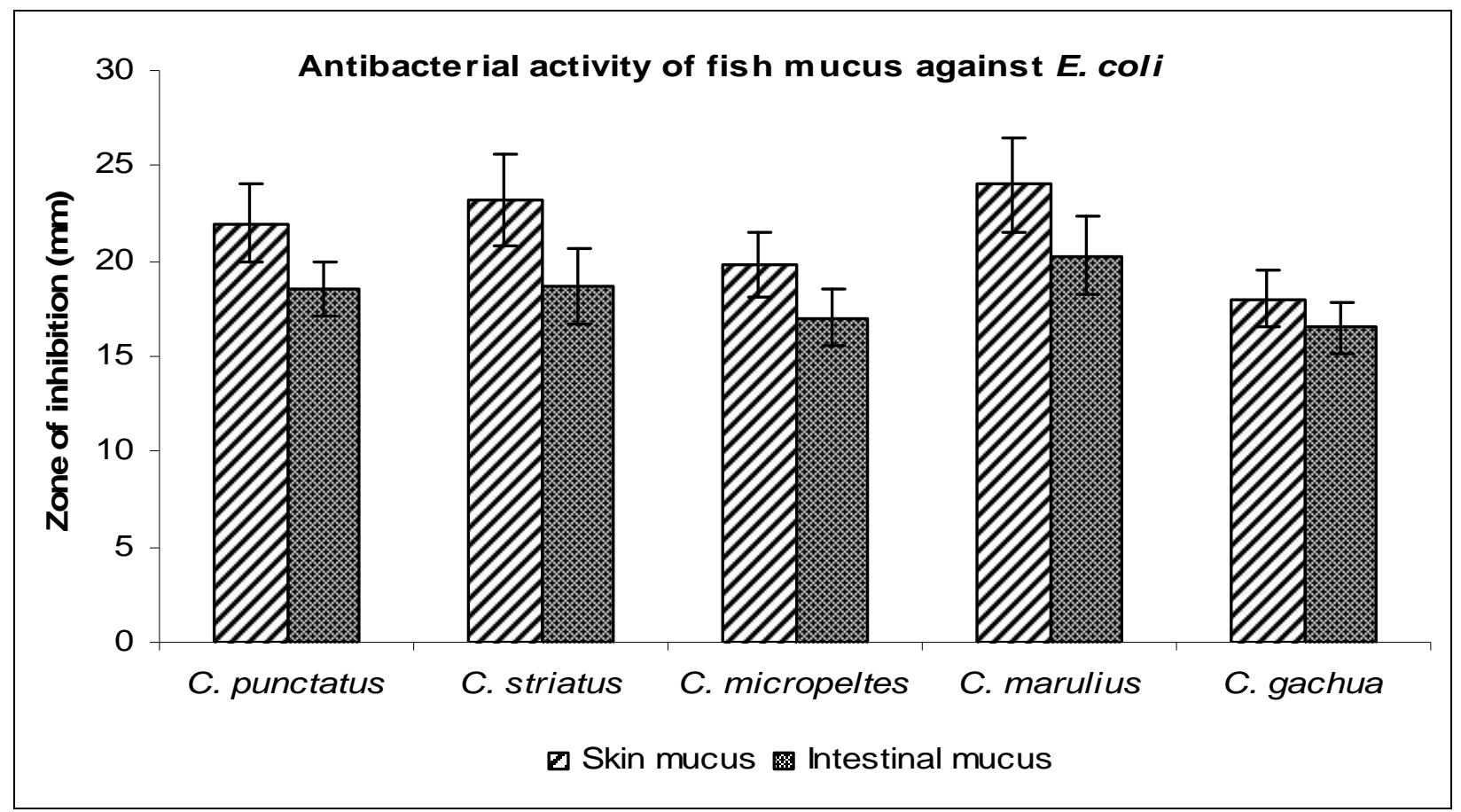

Figure 4. Antibacterial activity of skin mucus and intestinal mucus of five different Channa species against E. Coli.

\section{ACKNOWLEDGEMENTS}

The study was supported by the ICAR-NAIP Sub Project (F. No: 1 (5)/ 2007 - NAIP dt 22 August 2008) New Delhi sanctioned to Dr.M.A. Haniffa, Director CARE. The authors would like to thank Rev. Dr. Alphonse Manickam S.J, Principal St. Xavier's College for providing the necessary facilities and encouragement.

\section{REFERENCES}

1. Chandrasekaran M, Studies on the microbial spoilage of Penaues indicus, Ph.D. Thesis, Cochin University, Kerala (1985).

2. Mellor D J \& Stafford K J, Integrating practical, regulatory and ethical strategies for enhancing farm animal welfare, Australian Veterinary Journal, 79 (2001) 762.

3. Bressler $\mathrm{R} \mathrm{S} \&$ Bressler $\mathrm{C} \mathrm{H}$, Functional anatomy of the skin, Clin Podiatr. Med. Surg, 6 (1989) 229.

4. Ingram $\mathrm{G}$, Substances involved in the natural resistances of fish to infection, J. Fish Biol, 16 (1980) 23.

5. Shephard K L, Functions for Fish Mucus, Reviews in Fish Biology and Fisheries, 4 (1994) 401.

6. Austin B \& Mcintosh D, Natural Antibacterial Compounds on the Surface of Rainbow-Trout,
Salmo-Gairdneri Richardson, J.Fish.Dis, 11 (1988) 275.

7. Noya M, Magarinos B, Toranzo A E \& Lamas J, Sequential Pathology of Experimental Pasteurellosis in Gilthead Seabream Sparus aurata - a Light Microscopic and ElectronMicroscopic Study, Dis. Aq.Org, 21 (1995) 177.

8. Powell M D, Speare D J \& Burka J F, Fixation of Mucus on Rainbow Trout (Oncorhynchus mykiss walbaum) Gills for Light and ElectronMicroscopy, J. Fish Bio, 41 (1992) 813.

9. Blackstock N \& Pickering A D, Changes in the Concentration and Histochemistry of Epidermal Mucous Cells During the Alevin and Fry Stages of the Brown Trout Salmo-Trutta, J. Zool, 197 (1982) 463.

10 Cohen P S \& Laux D C, Bacterial adhesion to and penetration of intestinal mucus in vitro, Methods Enzymol, 253 (1995) 309.

11. Kuppulakshmi C, Prakash M, Gunasekaran G, Manimegalai G \& Sarojini S, Antibacterial properties of fish mucus from Channa punctatus and Cirrhinus mrigala, Eur. Rev. Med. Pharmacol. Sci, 12 (2008).

12. Van der Waaij $\mathrm{D}$, The digestive tract in immuno compromised patients: importance of maintaining its resistance to colonization, especially in hospital in-patients and those taking antibiotics, Antonie Van Leeuwenhoek, 50 (1984) 745. 
13. Ellis A, Immunity to bacteria in fish, Fish.Shellfish.Immunol, 9 (1999) 111.

14. Shephard K L, Functions for Fish Mucus, Reviews in Fish Biology and Fisheries, 4 (1994) 401.

15. Mat Jais A M, Dambisya $Y$ M \& Lee $T$ L, Antinocicepative activity of Channa striatus (Haruan) extracts in mice, J. Ethnopharmacol, 57 (1997) 125.

16. Somchit M N, Solihah M H, Israf D A, Ahmad Z, Arifah A K \& Mat Jais A M, Anti- inflammatory activity of Channa striatus, Channa micropeltes and channa lucius extracts: Chronic inflammatory modulation, J. Orient. Pharm. Exp. Med, 4 (2004) 91.

17. Zuraini A, Somchit M N, Solihah M H, Goh Y M, Arifah A K, Zakaria M S, Somchit N, Rajion M A, Zakaria Z A \& Mat Jais A M, Fatty acid and amino acid composition of three local Malaysian Channa sp, Fish. Food Chem, 97 (2005) 674.

18. Mat Jais A M, Zakaria Z A, Luo A \& Song Y X, Antifungal activity of Channa striatus (Haruan) crude extracts, Int.J.Trop.Med, 3 (2008) 43.

19. Birkemo G A, Luders T, Andersen O, Nes I F \& Nissen-Meyer J, Hipposin, a histone-derived antimicrobial peptide in Atlantic halibut (Hippoglossus hippoglossus L.), Biochimica Et Biophysica Acta-Proteins and Proteomics, 1646 (2003) 207.

20. Park I Y, Park C B, Kim M S \& Kim S C, Parasin I, an antimicrobial peptide derived from histone $\mathrm{H} 2 \mathrm{~A}$ in the catfish, Parasilurus asotus, FEBS Lett, 437 (1998) 258.

21. Alexander $\mathrm{J}$ B, \& Ingram G A, Noncellular nonspecific defense mechanisms of fish, Ann. Rev. Fish Dis, 2 (1992) 249. 